\section{CEC wants to double the money}

Paris

ThE Commission of the European Communities (CEC) has proposed that its European Community Action Scheme for Mobility of University Students (ERASMUS) should double its budget for the next three years. The proposal, expected to be debated at the Council of Ministers in December, would see the budget of 85 million ECU (1 European Currency Unit = $\$ 1 \cdot 1)$ for $1987-90$ rise to 192 million ECU for 1990-93. ERASMUS was launched in 1987 with a budget of 10 million ECU, rising to 45 million ECU by 1989 .

Its aim is to allow university students and teachers to spend periods of study abroad at universities in the 12 member states. But the success of the programme - applications exceed resources by a factor of three - has created problems. Students often find their grants inadequate and, in order to try to meet the demand, the length of the visits can be too short (between 3 months and a year).

In its first two years, ERASMUS enabled over 16,000 students to study at foreign universities within the Community. A goal of the Commission is that $\mathbf{1 0}$ per cent of the Community's 6.5 million students should profit from ERASMUS by 1993 . Furthermore, it is hoped that the average length of stay should rise to six months and eventually to a full year. But language learning, not officially part of the ERASMUS programme, has proved to be a stumbling block. While other programmes within the CEC, such as the recently proposed Lingua programme, expressly deal with foreignlanguage learning, the Commission would like to see a budget set aside within ERASMUS to integrate language studies within the study period. Peter Coles

\section{BRAZIL}

\section{SONDA lifts off}

\section{São Paulo}

ThE Brazilian Air Force late last month launched successfully the fourth prototype of its 7.5-tonne sounding rocket SONDA IV. The rocket carries a 500-kilogram payload and, according to the Air Force's Institute for Space Activities it reached an apogee of $820 \mathrm{~km}$. The SONDA series is the basis for the much bigger Satellite Launcher Vehicle (VLS), the rocket that will carry the Brazilian-built satellites in the next decade. VLS wil have four SONDA IV motors as strap-on boosters.

The satellites are being developed by the civilian Institute for Space Research (INPE).

The Air Force also announced that a reduced-scale version of VLS would be launched on 16 May.

Ricardo Bonalume Neto

\title{
Does it work efficiently?
}

\section{Chicago}

Although the peer-review process steers the scientific machine, the 250 participants at the world's first international congress on peer review, held in Chicago last week, turned out to have only the slenderest of evidence that peer review works either efficiently or fairly. At one extreme is the machiavellian picture of peer review painted by Erdem Cantenkin of the University of Pittsburgh. In his talk he described peer review as a "club" with the "same individuals significantly involved in funding, publication and academic peer review processes". Conflicts of interest arise, he says, "because the funding and publication successes of members of this exclusive club are determined largely by other members of the club".

At the other extreme lies an exalted view of peer review as an impersonal truth-producing machine that maintains the objectivity of science and purges all error from the system. While some members of Congress may hope for this, some of the studies presented at the conference suggest that journal peer review may not so much eliminate errors as ensure they are published in someone else's journal. Papers rejected by one journal often make their way down a hierarchy of journals, acquiring only slight or no modification on the way, until they find acceptance.

Ignorance of the true state of peer review is unlikely to remain acceptable. The US National Institutes of Health decides how to spend $\$ 7,000$ million a year through peer review and as Peter Budetti, a member of a congressional subcommittee on health and the environment, pointed out, the public wants to know its money is well spent. Accountability for scientific activities has been delegated to scientists through peer review, Budetti said. That means that the peer review process itself must be open to public inspection lest Congress enforce more direct accountability.

Bias is the commonest form of complaint; especially amongst those refused publication or promotion by secret peer review. But a study by the Journal of General Internal Medicine shows reviewers and editors may not be as bad as they are painted. Eliminating bias by hiding the names and affiliations of authors and the identity of reviewers had little effect on editors' recommendations.

Publication bias does appear in a more subtle form. Francis Bacon described it succintly in 1621 as the tendency of the human intellect to be "more moved and excited by affirmatives than by negatives". Several studies show positive results more likely to be published than negative ones. That practice may be stimulating but is dangerous: if clinical trials are reported only when successful then ineffective drugs may reach the market-place. One solution is to register all clinical trials at inception so that negative results that never appear can still be traced.

Multiple publication appears to be thriving and peer review ineffective to stop it. Byron Bailey, editor of the Archives of Otolaryngology - Head and Neck Surgery, carried out an eight-year medical database survey and found that of 1,000 of his authors, 228 had published 938 duplicate articles. In a third of the cases there was no reference to the companion publication. Bailey also warned of "salami slicing", where many papers are produced when one would be appropriate, and sequential publishing, where data are added without changes in concepts.

Outright cheating is also unlikely to be picked up by peer review. Most journal editors argued that the integrity of the data was the responsiblity of the research institution concerned.

Not all agreed because there are ways to check - random data audits of papers, conducted in the same spirit as income tax spot checks is one. But the recent Institute of Medicine report on The responsible conduct of research in the health sciences rejects data audits because they would would rarely pick up irregularities and would have "a chilling effect" on creativity and independence of science.

Once fraudulent work gets into the literature it is not easy to get it out again. Paul Friedman of the University of California at San Diego found that journals were loth to publish retractions of work found fraudulent and many had no procedures for handling such requests. But Institute for Scientific Information director Eugene Garfield's study was more encouraging. He showed that citations of papers publicly exposed as fraudulent quickly dropped off as authors shunned the work.

Peer review has already gone too far for David Horrobin of the Efamol Research Institute. His look at the period from 1930 to the present shows, he says, that innovation has gradually been traded for quality control. Two effective psychiatric treatments - lithium for manic depression and monoamine oxidase inhibitors for depression - would never make it through the current peer review system.

His solution is Medical Hypotheses, the only medical journal fully devoted to ideas. Horrobin agrees that "many innovators are off the wall and pains in the neck" but he believes the world needs them.

\section{Alun Anderson}

The proceedings of "Guarding the guardians: Research on peer review" will appear in the Journal of the American Medical Association this summer 